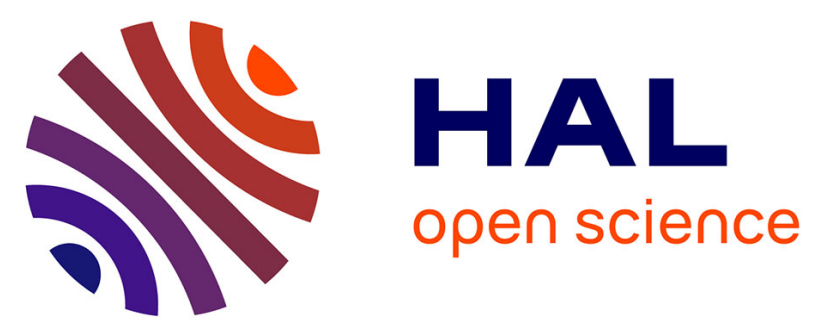

\title{
Magnetostratigraphy and rock magnetism of the Neogene Kuitun He section (northwest China): implications for Late Cenozoic uplift of the Tianshan mountains.
}

Julien Charreau, Yan Chen, Stuart A. Gilder, Stéphane Dominguez, Jean-Philippe Avouac, Sevket Sen, Dongjiang Sun, Yongan Lif, Wei-Ming Wang

\section{- To cite this version:}

Julien Charreau, Yan Chen, Stuart A. Gilder, Stéphane Dominguez, Jean-Philippe Avouac, et al.. Magnetostratigraphy and rock magnetism of the Neogene Kuitun He section (northwest China): implications for Late Cenozoic uplift of the Tianshan mountains.. Earth and Planetary Science Letters, 2005, 230, pp.1-2, 177-192. 10.1016/j.epsl.2004.11.002 . hal-00023363

\section{HAL Id: hal-00023363 \\ https://hal-insu.archives-ouvertes.fr/hal-00023363}

Submitted on 23 May 2006

HAL is a multi-disciplinary open access archive for the deposit and dissemination of scientific research documents, whether they are published or not. The documents may come from teaching and research institutions in France or abroad, or from public or private research centers.
L'archive ouverte pluridisciplinaire HAL, est destinée au dépôt et à la diffusion de documents scientifiques de niveau recherche, publiés ou non, émanant des établissements d'enseignement et de recherche français ou étrangers, des laboratoires publics ou privés. 


\title{
Magnetostratigraphy and rock magnetism of the Neogene Kuitun He section (northwest China): implications for Late Cenozoic uplift of the Tanshan mountains
}

\author{
J ulien Charreau ${ }^{\alpha}$, Yan Chen $₫$, Stuart Gilderº, Stéphane Dominguezc, J ean-Philippe

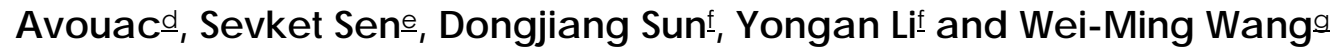

anstitut des Sciences de la Terre d'Orléans; Bâtiment Gésciences, rue de Saint Amand, BP 6759, 45067 Orléans Cedex 2, France

bInstitut de Physique du Globe de Paris; Laboratoire de Paléomagnetisme, 4 place Jussieu, 75252 Paris Cedex 05, France

CLaboratoire Dynamique de la Lithosphére; UMR CNRS/UMII 5573, Bâtiment 22 (cc.

60) Place Bataillon, 34095 Montpellier Cedex, France

aCalifornia Institute of Technology; Division of Geological and Planetary Sciences,

Mail Code 100-23, Pasadena, CA 91125 , United States

eMuseum of Natural History, Paris; Departement de Paleobiodiversité: Histoire et

Dynamique, 43 rue Buffon, 75005 Paris Cedex 5, France

fInstitute of Geology and Mineral Resources, Bureau of Geology and Mineral

Resources of Xinjiang Uygur Autonomous Region, Urumqi, China

sDepartment of Palaeobotany and Palynology, Nanjing Institute of Geology and

Palaeontology, Chinese Academy of Sciences, 39 East Beijing Road, Nanjing 210008 ,

PR China

\begin{abstract}
In order to better constrain the tectonic evolution of central Asia under the influence of the India-Asia collision, we carried out a magnetostratigraphic study at the Kuitun He section, on the northern flank of the Tianshan range (northwest China). A total of 801 samples were collected from a 1559-m-thick section, which is composed mainly of fluvio-lacustrine sandstone and conglomerate. Stepwise thermal and alternating field demagnetization isolated a linear magnetization component that decays univectorally toward the origin and likely represents a primary magnetization principally carried by magnetite. From this component, 29 magnetic polarity intervals were identified. They correlate between $\approx 3.1$ and $\sim 10.5 \mathrm{Ma}$ with the reference magnetic polarity time scale, indicating a relatively constant sedimentation rate with an average of $0.21 \pm 0.01 \mathrm{~mm} /$ year. We also performed a suite of rock magnetic experiments designed to track time-transgressive changes in the sedimentary record. From the rock magnetic parameters, together with the constant sedimentation rate, we conclude that the Tianshan mountains were actively uplifting by m10.5 Ma.
\end{abstract}

Keywords: Tianshan; uplift; magnetostratigraphy; AMS

\section{Introduction}

The vast region from India to central Asia contains the highest mountain ranges and is among the most rapidly deforming intracontinental areas on Earth today. Tectonic deformation driven by the India-Asia collision, which started some $50 \mathrm{Ma}$ ago [1], has impacted global climate [2], [3] and [4]. Thus, understanding how and when the 
topography was built has a wide range of implications for the Earth Sciences spanning from tectonics to climate change. Given the immensity of the region, it is natural that the timing and the way in which the topography formed remain poorly understood, with models ranging from a systematic south to north propagation of deformation [5] and [6] to a more sporadic evolution in time and place [7] and [8].

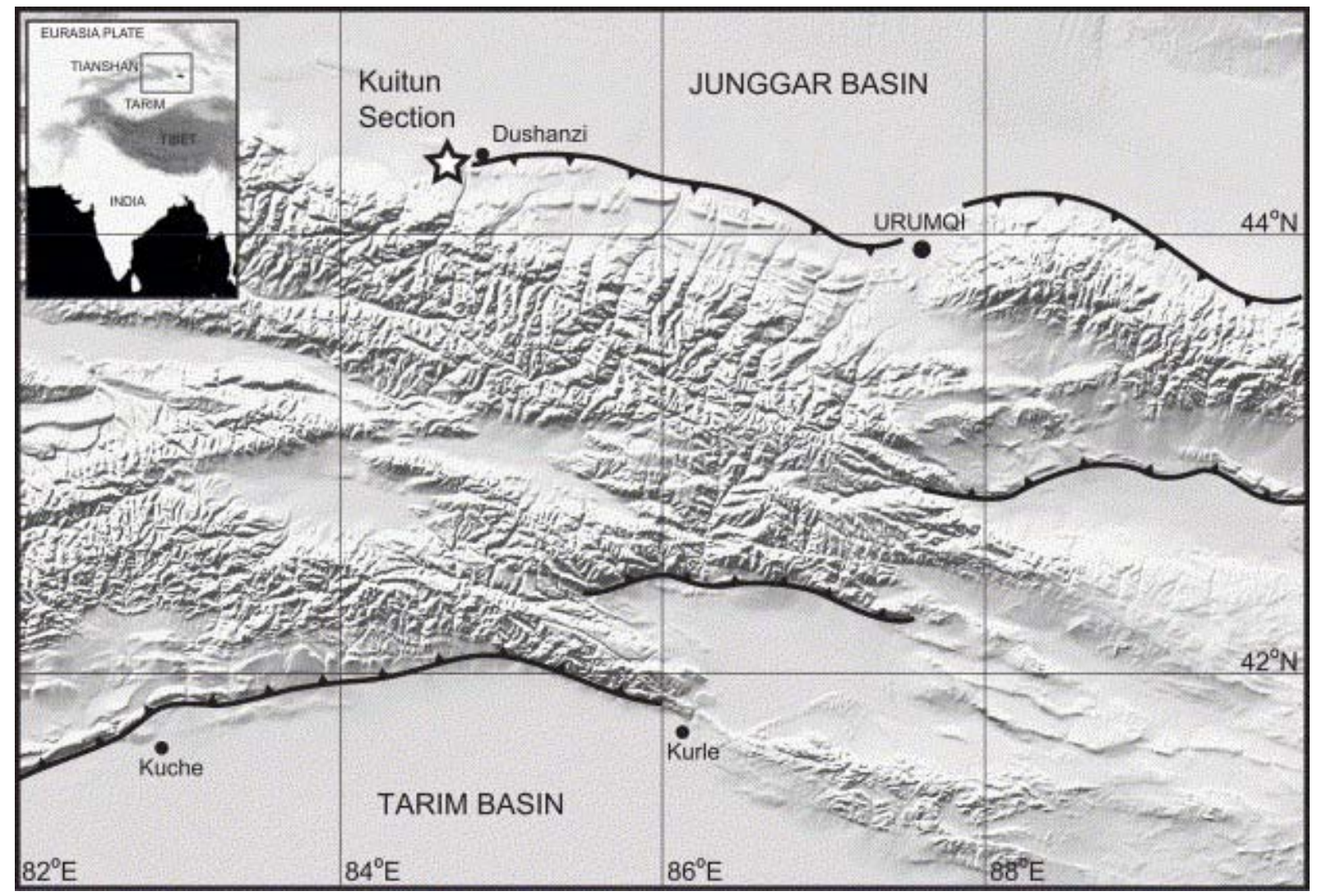

Fig. 1. Topographic map of central Asia.

The Tianshan mountains lie some $2000 \mathrm{~km}$ north of the initial collision front. It is one of the largest mountain ranges in Asia (Fig. 1), with summits higher than $7000 \mathrm{~m}$ dominating the landscape over an E-W distance of $2500 \mathrm{~km}$. They separate the Tarim basin to the south from the Junggar basin to the north. The geological structure of the range has resulted from a complex Paleozoic history of subduction-related processes [9] and [10], later reactivated in the Cenozoic. Modern tectonism is attested by high levels of seismicity and active faulting [7]; GPS measurements suggest shortening rates reach $\approx 20 \mathrm{~mm} /$ year across the western Tianshan, where the range is widest [111, and about $6 \mathrm{~mm} /$ year across the central Tianshan [11] and [12]. While the present-day high topography is attributed to the Cenozoic India-Asia collision, the timing of the onset of the Cenozoic reactivation is poorly constrained. Most estimates fall within the Miocene, between 10 and $24 \mathrm{Ma}$ [5], [7], [11], [13], [14], [15], [16] and [17]. 
Near Urumqi (Fig. 1), Windley et al. [10] described an angular unconformity at the base of the Oligocene followed by an increase in the rate and energy of sedimentation, which they interpreted as marking the onset of deformation induced by the India-Asia collision. Yang and Liu [16] proposed that uplift of the Tianshan started during or before Oligocene based on flexural modelling and sedimentological constraints of the Tarim basin. Fission track dating of detrital apatites in Mesozoic sandstone led Hendrix et al. [14] to place the initiation of Tianshan uplift at about $24 \mathrm{Ma}$.

In both the Junggar and the Tarim basins, the upper Cenozoic is marked by the deposition of a thick conglomerate unit, named the Xiyu Formation [18], which led Burchfiel et al. [15] and Fu et al. [17] to suggest that the major uplift of the Tianshan occurred in the latest Cenozoic to Quaternary. On the other hand, such a youthful uplift cannot fully account for the high relief that reaches more than $7000 \mathrm{~m}$, and it is possible that the thick conglomerates owe their origin to climate change rather than to tectonic exhumation [18].

Based on balanced cross sections, Avouac et al. [13] estimated that the initiation of the deformation across the Tianshan began at $15 \mathrm{Ma}$, assuming a constant shortening rate of about $3 \mathrm{~mm} /$ year across the north Tianshan piedmont. Métivier and Gaudemer [5] placed the beginning of major uplift at $16 \mathrm{Ma}$, based on calculated mass accumulation rates in the Junggar basin. Their analyses show that the accumulation rate accelerated at $5 \mathrm{Ma}$, which could indicate an acceleration of Tianshan uplift at that time. However, their database is derived from continental sediments that are notoriously fossil-poor, hence the uncertainties are extremely large. By extrapolating the current shortening rate derived from GPS measurements to the past, and assuming that the total shortening rate across western Tianshan is around $200 \mathrm{~km}$ [13], Abdrakhmatov et al. [11] suggested that most of Tianshan was constructed during the past $10 \mathrm{Ma}$. In the Chu basin of the western Kyrgyz Tianshan, Bullen et al. [19] and [20] carried out a combined magnetostratigraphic and thermochronologic (fission tracks and U-Th/He) study and found that rapid exhumation started by $\approx 11 \mathrm{Ma}$.

In order to better constrain the timing of uplift, we carried out a magnetostratigraphic and rock magnetic study along the Kuitun River on the northern flank of the Tianshan range (Fig. 1). The Kuitun section contains a continuous, thick and beautifully exposed sequence of fluvio-lacustrine sediments. Because the sediments surrounding the Tianshan mountains record the erosion history of the chain, by studying these sediments one can learn details about mass transfer from the growing mountains to the surrounding basins, which should largely be a function of climate and tectonic processes. A significant obstacle, however, is that the sediments are continental in origin and are difficult to date via classic paleontologic methods. Thus, magnetostratigraphy is often used to date sediments and establish sedimentation rates. Moreover, by studying variations in the magnetic mineralogy of the sediments through time, one can learn more about changes in the sediment source and transport history. Below we report our magnetostratigraphic, paleontologic, structural geologic and rock magnetic results from this section and discuss their implications on the growth of the middle segment of the Tianshan mountains. 


\section{Geological setting and sampling}

Tianshan's northern flank is mainly composed of Mesozoic to Quaternary sediments that were folded in a set of east-west-striking ramp anticlines and exhumed along north verging thrust faults [13] and [15]. In places, north-trending rivers incise the anticlines perpendicular to strike, exposing the sediments. The Dushanzi region is one typical example where the north-flowing Kuitun River has cut one of these ramp anticlines, referred to as anticline A7 by Avouac et al. [13] and as the Dushanzi anticline by Burchfield et al. [15] (Fig. 2). Based on a balanced cross section and assuming a detachment-fault depth of about $5.75 \mathrm{~km}$ from seismic profiles, Burchfield et al. [15] estimated the Dushanzi section has been shortened by 2 to $2.5 \mathrm{~km}$.

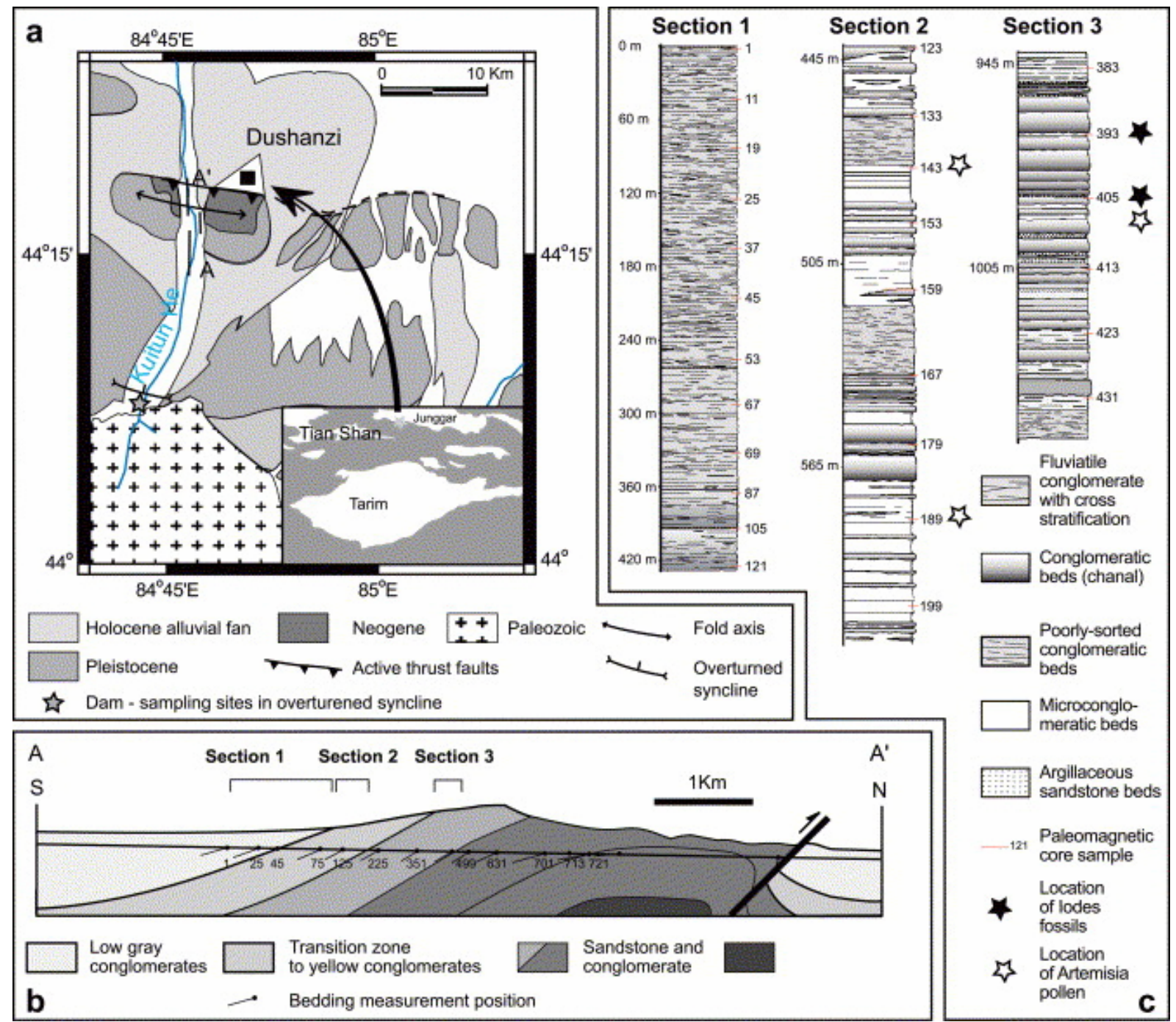

Fig. 2. (a) Geological map of the Dushanzi area (after Avouac et al. [13]) showing the Kuitun magnetostratigraphic section and the sampling sites farther south; (b) cross section of the Kuitun He anticline indicating the position of the paleomagnetic cores; (c) partial stratigraphic logs of the Kuitun He section (positions indicated in (b)). 
Sediments in the Kuitun section are mapped as the Neogene Dushanzi Formation based only on facies correlation; no known fossils have been described at this section [21]. We carried out an intensive paleontological investigation throughout the section; unfortunately, the rare macroscopic remains we found are only vegetal stones of the genus lodes that have an age span from Eocene to Present. However, the presence of lodes is indicative of a hot and wet paleoenvironment as they are currently known in the tropical regions of Africa, India and Madagascar. Such a humid environment may also explain the poor fossil preservation. The spore and pollen composition of 4 samples was also investigated (Fig. 2). The occurrence of Artemisiae pollenites (Artemisia) is somewhat significant. The earliest recorded pollen grains of this genus are from the Oligocene but it did not thrive until the Middle to Late Miocene. Artemisia underwent a major period of radiation in the Pliocene, while the Quaternary is an important period in the diversification and worldwide expansion of the genus.

Thick green-grey conglomerate and yellow coarse sandstone dominates the upper part of the section (Fig. 2), which probably corresponds to the Xiyu Formation that is widely recognized on both the north and south flanks of the Tianshan mountains [15] and [21]. The only biostratigraphic control of the Xiyu Formation is the presence of Equus sameniensis at the transition zone with the Dushanzi Formation in a nearby section $15 \mathrm{~km}$ to the east [15] and [21]. At the Kuitun section, it is difficult to clearly delimit the Neogene Dushanzi Formation from the overlying Xiyu Formation. The series becomes progressively fine grained toward the base, being composed predominantly of dark red to yellow sandstone and siltstone. Burchfiel et al. [15] proposed that these strata are Lower Neogene in age. Approaching the anticline from the south, the conglomerate beds are flat-lying, then they become progressively folded with dips reaching $38^{\circ}$, before becoming horizontal at the heart of the anticline. The general structure is consistent with a fault-bend fold [13] and [15] with the variation of dip angles reflecting either the geometry of the basal thrust fault, thought to sole into a sub-horizontal decollement, or due to syntectonic sedimentation within the piggy-back basin. No significant fault or major discordance was observed in the section, suggesting that sedimentation was relatively continuous without any duplication.

The sampled section spans $1559 \mathrm{~m}$ in thickness. In the conglomerate-rich and poorly consolidated part of the top $444 \mathrm{~m}$ of the section, collecting samples with a gasoline powered drill was impossible, so we took 74 oriented hand samples from the least coarse horizons by inserting plastic cubes into the sediment then orienting the cubes. The sampling density is relatively low with an average thickness of about $7.5 \mathrm{~m}$ between each sampling layer. A total of 727 paleomagnetic cores were drilled over a stratigraphic thickness of $\sim 1120 \mathrm{~m}$ in the lower part of the section where lithologies were amenable to such sampling methods (Fig. 2). At least two cores per horizon were collected with an average distance between horizons of $5.6 \mathrm{~m}$. Cores were oriented using magnetic and sun compasses whenever possible. The average magnetic declination anomaly is $2.0 \pm 2.6^{\circ}(n=206)$, with the mean value being used to correct the cores lacking sun compass corrections. Bedding attitudes were measured at each sampling layer and core locations were determined to within a few centimetres using differential GPS. In order to obtain a significant fold test, we sampled three sites several kilometres to the south, where coeval to slightly older sediments are overturned in a tight syncline (Fig. 2). At this locality, one clearly 
observes a progression in folding during sedimentation in the upper levels of the section.

\section{Laboratory treatment}

\subsection{Analytical techniques}

In the laboratory, cores were cut into standard specimens of $2.5 \mathrm{~cm}$ in diameter and $2.2 \mathrm{~cm}$ in length. The samples were subjected to a suite of analyses including: thermal magnetic (Curie point) experiments using an AGICO KLY-3S kappabridge susceptibility-meter coupled with a CS3 furnace, acquisition of isothermal remanent magnetization (IRM) using an IM30 pulse magnetizer, anhysteretic remanent magnetization (ARM) using a LDA-3 demagnetizer, as well as anisotropy of magnetic susceptibility (AMS) measurements using a KLY3 kappabridge susceptibility meter at the Laboratoire du Magnétisme des Roches d'Orléans (LMRO). We also measured magnetic hysteresis curves at the Institut de Physique du Globe de Paris (IPGP). Both thermal and alternating magnetic field (AF) demagnetization was applied to clean the magnetic remanence at LMRO and IPGP. On poorly consolidated samples, AF demagnetization was applied using a $2 \mathrm{G}$ in-line three-axis AF demagnetizer (IPGP) and the magnetic remanence was measured using a $2 G$, three-axis DC SQUID magnetometer (IPGP). Other samples were demagnetized with a laboratory built furnace or LDA-3 AF demagnetizer (LMRO) and magnetic remanence was measured with a JR-5A automatic spinner magnetometer (LMRO). Magnetic remanence directions were determined by principal component analysis [22] and the mean directions were computed with Fisher [23] statistics, both using paleomagnetic software packages of [24] and R. Enkin (unpublished).

\subsection{Magnetic mineralogy}

Fig. 3 presents representative results of the rock magnetic experiments. IRM increases rapidly from 0 to $150 \mathrm{mT}$, with up to $70 \%$ of the maximum magnetization attained by $150 \mathrm{mT}$, yet the samples are not totally saturated by 1 Tesla, indicating the dominance of a rather soft coercive magnetic mineral with a minor contribution of a mineral with higher coercivity (Fig. $3 a, c$ and e). Curie temperature measurements show an important drop of magnetic susceptibility around $580{ }^{\circ} \mathrm{C}$, characteristic of titanium-poor magnetite. More moderate inflections are observed at 150, 400 and above $600{ }^{\circ} \mathrm{C}$, which likely reflect the presence of iron hydroxide (limonite), maghemite and hematite, respectively (Fig. 3b, $d$ and f). Hysteresis loops are not particularly wasp-waisted (Fig. $3 \mathrm{~g}$ ). The thermomagnetic results, together with the demagnetization characteristics (below), indicate that titanium-poor magnetite is the dominant magnetic mineral in all samples. 

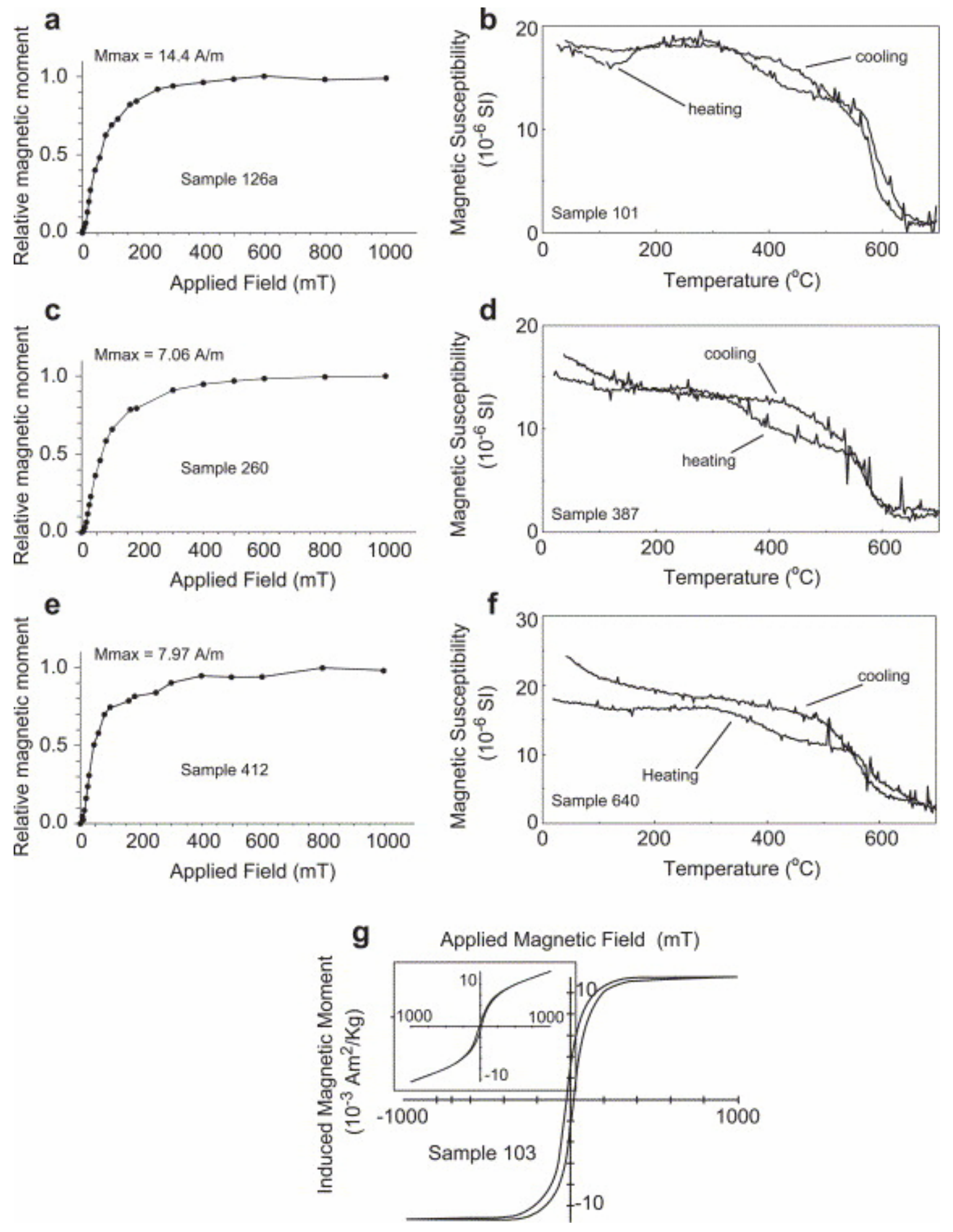

Fig. 3. Rock magnetic investigations of representative samples: (a, c, e) isothermal remanent magnetization; $(b, d, f)$ Curie point analyses; ( $g$ ) hysteresis loop.

\subsection{Remanent magnetization}

Well-consolidated samples were subjected to either thermal or AF demagnetization methods, whereas hand samples were only subjected to AF demagnetization (Fig. 
4). Both demagnetization techniques usually isolated two components: one at low temperatures $\left(20\right.$ to $200^{\circ} \mathrm{C}$ ) or weak AF fields $(<10 \mathrm{mT})$ that did not decay toward the origin (here called component 1), and another at high temperatures (200 to 580 or $680^{\circ} \mathrm{C}$ ) or stronger AF fields (>10 mT) that normally decayed toward the origin on orthogonal diagrams (here called component 2).
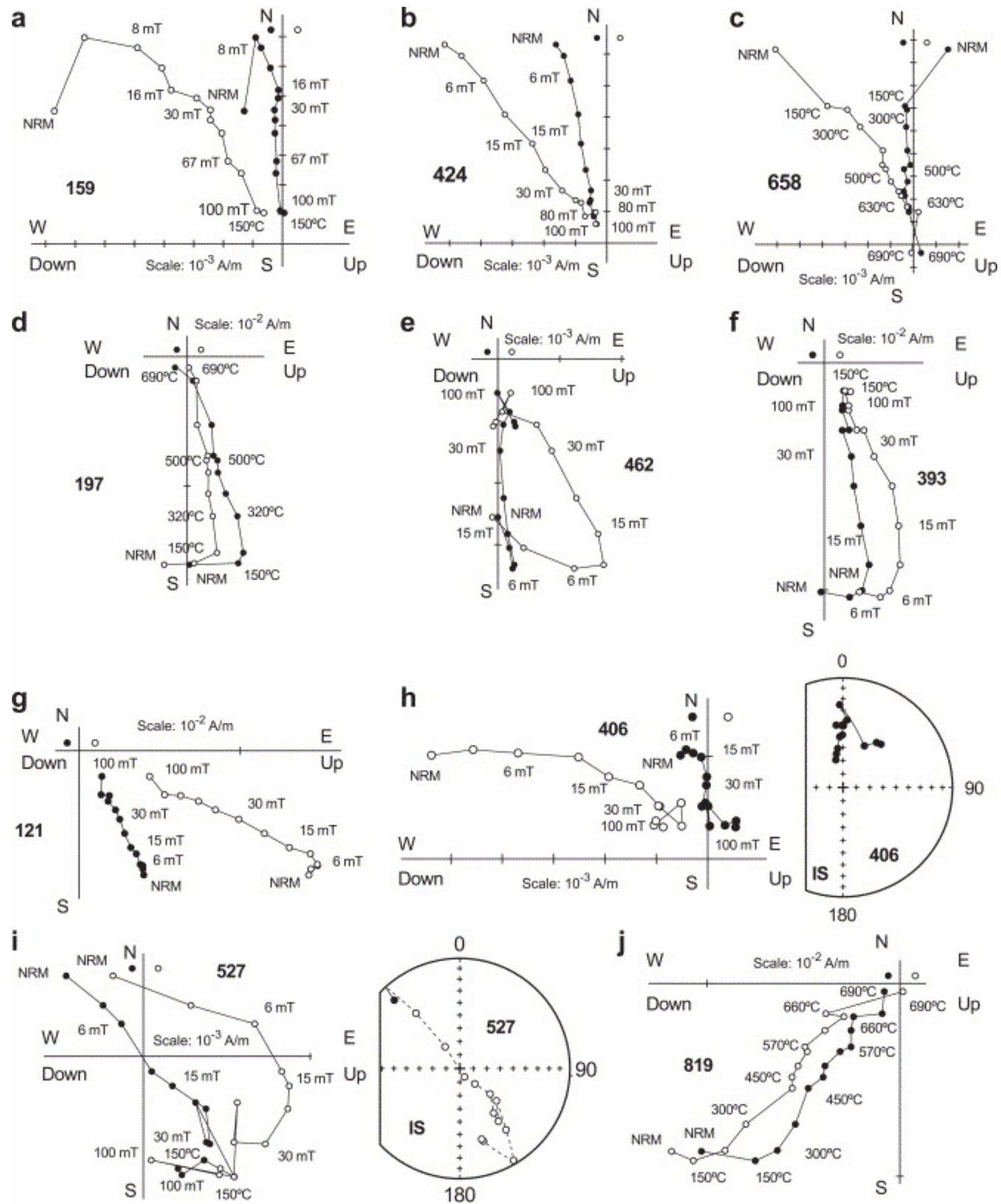

Fig. 4. Representative Zijderveld diagrams [47] obtained from both thermal and alternating field (AF) demagnetization (in situ coordinates). 
Component 2 is normally completely unblocked at peak AF fields of $100 \mathrm{mT}$ or temperatures of $580{ }^{\circ} \mathrm{C}$, which is again characteristic of magnetite. However, in some samples $20 \%$ or more of the original NRM intensity remains after $580^{\circ} \mathrm{C}$, which persists until $680^{\circ} \mathrm{C}$ (Fig. $4 \mathrm{C}$ and d). The latter is characteristic of hematite. When both magnetite and hematite were present in the same sample, no significant difference in remanent direction was observed when comparing the 500 to $580{ }^{\circ} \mathrm{C}$ with the 600 to $680{ }^{\circ} \mathrm{C}$ parts of the unblocking spectra (Fig. 4C and d). This suggests that both magnetic carriers recorded the same paleomagnetic field when their remanences became fixed in the rock. For $7 \%$ of the samples, the remanence trajectories are spread out about a great circle while never reaching a stable endpoint (Fig. 4i). In these cases, the great circle technique was applied to estimate the polarity. Hand samples collected from the least coarse horizons in the upper conglomeratic part of the section yielded coherent magnetic directions (Fig. 4g), and the magnetic directions isolated from these samples unambiguously identified the magnetic polarity.

About 60 samples have an important proportion of their NRMs that are north and downward directed in geographic coordinates, whose directions in tilt-corrected coordinates are eastward with very steep (up to $70^{\circ}$ ) inclinations (Fig. 4h). Most of these samples show a coherent component isolated at higher temperatures or higher maximum applied fields. However, about $4 \%$ of the samples show only this steep remanence. An interesting point is that most of these samples come from the eastern side of the Kuitun River, on more weathered outcrops, as opposed to the western side of the river where the incision creates steep, freshly cut cliff faces.

Magnetic component 1 normally comprises less than $20 \%$ of the total NRM and yields dispersed directions in both geographic (precision parameter, $\mathrm{kg}$, is 6.4) or stratigraphic $(k s=6.0)$ coordinates (Fig. 5a). Although the mean direction does not coincide with either the present-day field or geocentric axial dipole direction at the site, the predominance of normal polarity suggests that component 1 represents a Bruhnes-field magnetization contaminated by drilling-induced and/or viscous magnetizations. To test this, we placed 24 samples, previously AF demagnetized to $100 \mathrm{mT}$, in a $10^{4} \mathrm{nT}$ field for 8 days, measured the remanence, then reversed the field for another 8 days, then measured the remanence again. This experiment shows $30 \%$ of the NRM is due to a viscous magnetization oriented in the applied field direction. Among the 500 demagnetized specimens, 360 exhibited stable magnetic component 2 vectors, which come from 230 individual horizons that were used to establish the magnetostratigraphic column. The polarities of eight horizons were determined by the great circle technique. Both normal (114 horizons) and reverse (116 horizons) magnetic polarities were identified in roughly equal proportion. 

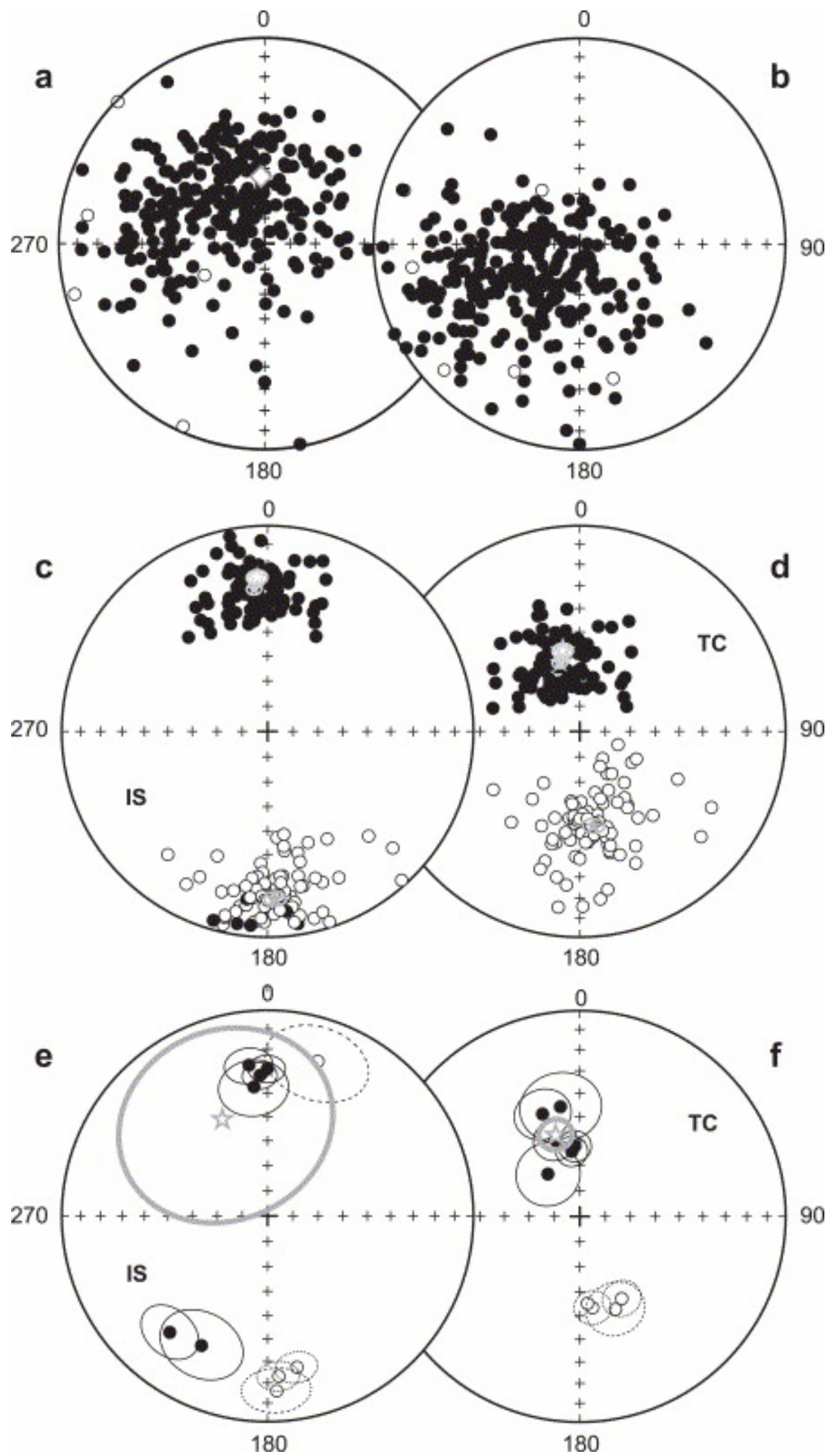

Fig. 5. Equal area projections of: (a, b) component 1 directions (276 samples); (c, d) component 2 directions (182 samples); (e, f) the 10 site mean directions, in in situ and tectonic corrected coordinates, respectively. Diamond (a) shows the Present Earth's field direction and grey (open) stars represent the (overall) mean directions in both polarities. 
Although 230 samples defined magnetic polarity, 48 were omitted when calculating the overall mean direction. We excluded samples that lay $>40^{\circ}$ from the mean (these samples were assumed to have recorded a transitional geomagnetic field) and the hand samples collected from the upper part of the section, which due to the sampling method have larger degrees of uncertainty associated with their orientations. Assuming a Fisherian distribution, the overall mean direction in geographic (g) and stratigraphic (s) coordinates is $D g=356.2^{\circ}, \mathrm{lg}=25.8^{\circ}, \mathrm{kg}=22.4$, $a_{959}=2.4^{\circ}$ and $D s=348.1^{\circ}, I_{s}=57.6^{\circ}, k s=21.3, a_{95 s}=2.4^{\circ}$, respectively, where $D$ is declination, $l$ is inclination, $k$, as above is the precision parameter and $a_{95}$ is the radius that the mean direction lies within $95 \%$ confidence. The overall mean direction in geographic coordinates (is different at $95 \%$ confidence limits from both the present Earth field and geocentric dipole field directions. The mean direction in stratigraphic coordinates using Fisher statistics is similar to that using the bootstrap method $\left(D s=347.3^{\circ}, I s=59.4^{\circ}\right)[25]$. On the other hand, the reversal test is negative at the $95 \%$ confidence level [26], largely because the mean inclination of normal (N) polarity directions are $10.2^{\circ}$ steeper $\left(D_{N}=344.2^{\circ}, I_{N}=61.6^{\circ} a_{95 N}=2.8^{\circ}\right)$ than that of the reverse (R) polarity directions $\left(D_{R}=177.6^{\circ}, I_{R}=-51.6^{\circ}, a_{95 R}=3.8^{\circ}\right)$. This is likely due to a partially unremoved recent field magnetization.

The three sites sampled south of the Dushanzi anticline yielded similar demagnetization characteristics as those from the Kuitun section (Fig. 4j) and possess both normal and reverse polarities (sites A, B and C in Table 1). In order to perform a meaningful fold test, we divided the 444 to $1559 \mathrm{~m}$ part of the magnetostratigraphic section into 7 sites with each site representing about $150 \mathrm{~m}$ in thickness (Table 1). Fig. $\underline{5 e}$ and $f$ show the stereonet plots of the 10 site mean directions before and after bedding corrections, where one quickly sees an improvement in clustering of the directions after bedding correction with $\mathrm{ks} / \mathrm{kg}=31$ ( $\mathrm{Dg}=335.1^{\circ}, \mathrm{lg}=46.9^{\circ}, \mathrm{kg}=2.3$ and $a_{959}=41.0^{\circ}$ before bedding correction and $D s=344.7^{\circ}, l_{s}=55.9^{\circ}, k s=71.9$ and $a_{95 s}=7.3^{\circ}$ after bedding correction). The fold test is positive at the $99 \%$ confidence level [27].

Sites A-C come from the southern flank of the Kuitun He anticline. Subsections 1 to 7 come from the magnetostratigraphic section. Abbreviations are: $n$, number of samples; S, strike; $d$, dip; $D$, magnetic declination; I, magnetic inclination; $g$, geographic coordinates; $s$, stratigraphic coordinates; $k$, precision parameter; $a_{95}$, radius of the cone in which the mean direction lies within $95 \%$ confidence. 


\begin{tabular}{|l|l|l|l|l|l|l|l|l|l|l|}
\hline Site & Thickness $(\mathbf{m})$ & $\boldsymbol{S}$ & $\boldsymbol{d}$ & $\boldsymbol{n}$ & $\left.\mathbf{D g} \mathbf{(}^{\circ}\right)$ & $\left.\mathbf{I g} \mathbf{(}^{\circ}\right)$ & $\mathbf{D s}\left(^{\circ}\right)$ & $\boldsymbol{I s}^{\left({ }^{\circ}\right)}$ & $\boldsymbol{k}$ & $\left.\boldsymbol{a}_{\mathbf{9 5}} \mathbf{(}^{\circ}\right)$ \\
\hline 1 & $450-600$ & 195 & 32 & 29 & 169.3 & 26.7 & 153.6 & -53.6 & 14.1 & 7.4 \\
\hline 2 & $600-750$ & 185 & 30 & 32 & 176.6 & 23.3 & 172.2 & -53.2 & 14.3 & 7.0 \\
\hline 3 & $750-900$ & 185 & 32 & 23 & 0.1 & 29.6 & 342.3 & 58.4 & 24.2 & 8.3 \\
\hline 4 & $900-1050$ & 188 & 33 & 24 & 353.4 & 27.4 & 342.3 & 58.4 & 13.6 & 8.3 \\
\hline 5 & $1050-1200$ & 193 & 35 & 19 & 177.2 & 16.6 & 58.4 & -50.1 & 10.1 & 11.1 \\
\hline 6 & $1200-1250$ & 193 & 35 & 17 & 354.9 & 37.8 & 323.6 & 69.8 & 9.0 & 12.6 \\
\hline 7 & $1250-1600$ & 187 & 36 & 38 & 357.3 & 32.7 & 353.9 & 64.0 & 15.5 & 6.1 \\
\hline A & & 187 & 105 & 13 & 220.2 & 27.8 & 340.8 & 46.6 & 16.1 & 10.6 \\
\hline B & & 187 & 105 & 8 & 207.6 & 30.5 & 350.0 & 45.8 & 14.5 & 15.0 \\
\hline C & & 190 & 100 & 6 & 18.2 & 22.6 & 175.4 & -55.3 & 15.6 & 17.5 \\
\hline Average & & & & 10 & 335.1 & 46.9 & - & - & 2.3 & 41.0 \\
\hline & & & & & - & - & 344.7 & 55.9 & 71.9 & 7.3 \\
\hline \hline
\end{tabular}

Table 1. : Site-mean paleomagnetic directions from this study

\section{Magnetostratigraphy}

Given the positive fold test and presence of dual polarities in nearly equal proportion, we conclude that the component 2 directions represent primary remanent magnetizations carried predominantly by magnetite. We thus used the component 2 directions, complimented by the polarity information from the great circle analyses, to construct a magnetostratigraphic polarity sequence of the Kuitun section. Fig. 6a and b show magnetic inclination and declination of the samples with respect to their corresponding stratigraphic position. Sixteen normal magnetic chrons ( 1 to 15 ) and 14 reverse ones (a to $n$ ) are identified (Fig. 6c). Among the 29 magnetic chrons, two lie within a single sedimentary layer (chrons 11 and $n$ in Fig. 6c). For these two horizons, the polarity was confirmed by demagnetizing a second sample from that same layer. The upper $444 \mathrm{~m}$ of the section (shaded in Fig. 6a and b) has a sampling density of 0.06 samples/m while from $444 \mathrm{~m}$ to $1559 \mathrm{~m}$ depth, it is 0.17 samples/m, meaning that the polarity chrons from upper part of the section are less well constrained. 

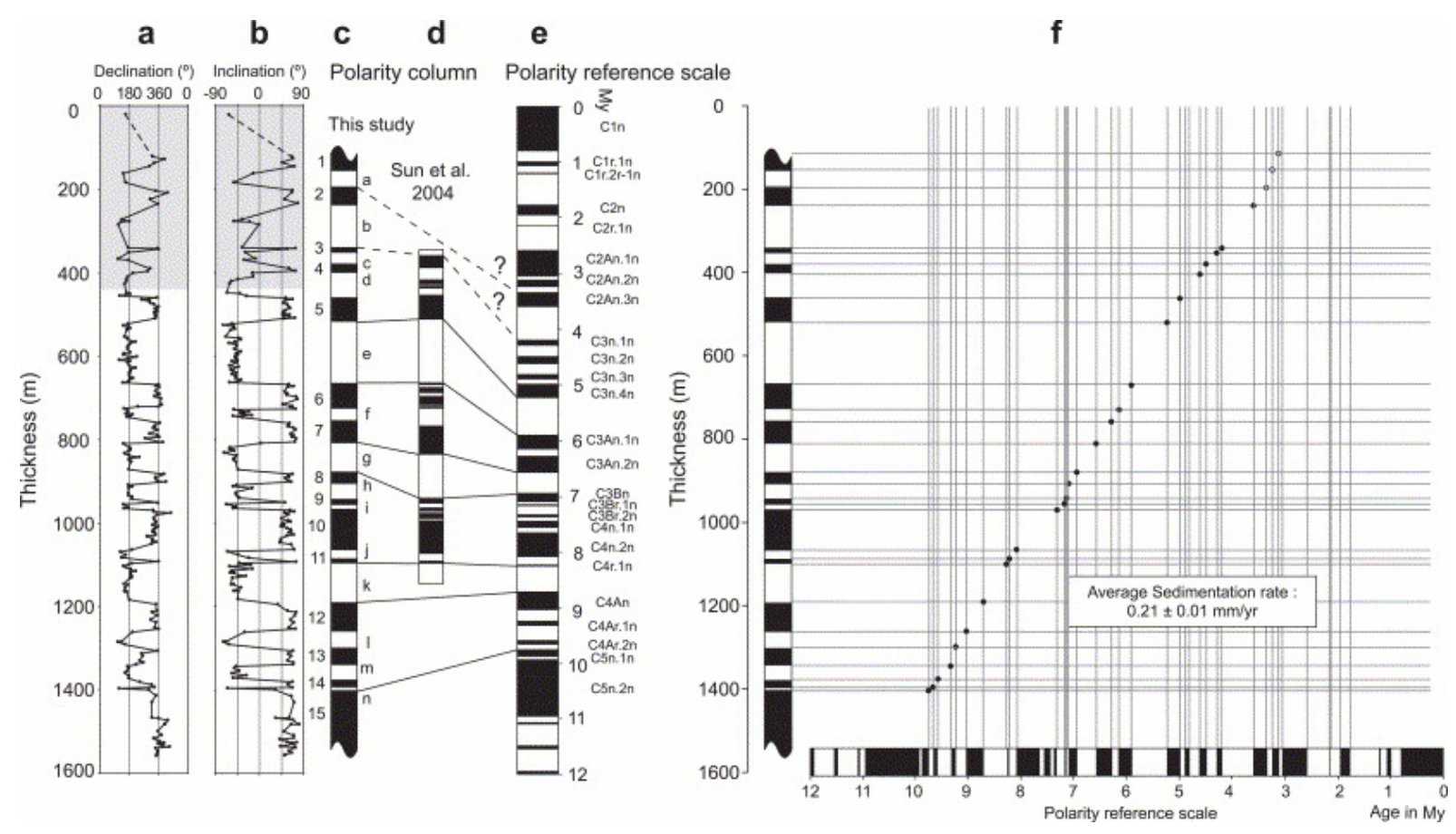

Fig. 6. (a) Magnetic declination and (b) magnetic inclination corresponding to the samples fit with principal component analysis. The shaded area corresponds to the conglomerate-rich Xiyu Formation. (c) Magnetostratigraphic column from this study and (d) from Sun et al. [23]. (e) Reference polarity time scale after Berggren et al. [28]; (f) age versus depth plot of the Kuitun section, using the data and correlation from (c) and (e).

The resulting magnetostratigraphic column (Fig. 6c) has a relatively high number of reversals, which to first order is consistent with the reference magnetostratigraphic scale for the middle to upper Tertiary [28]. The Kuitun column is characterized by three relatively long reversed periods $b, e$ and $k$ with one relatively long normal chron (15) at the base of the section (Fig. 6c). We used the following criteria to match the Kuitun magnetostratigraphy to the reference scale [28] (Fig. 6e): (1) the four relatively long magnetic chrons, (2) the absence of significant hiatuses or faults throughout the section, (3) the probability that the Kuitun $\mathrm{He}$ section lies within the Neogene [15] and [21], (4) the presence of lodes, which provides a maximum age of Eocene and (5) the presence of $A$. pollenites that likely indicates a Miocene or younger age. Our preferred correlation is shown in Fig. $6 c$ and $e$, which presents the best available fit in terms of interval number and duration. With respect to the reference column, problems in correlation lie between chrons 4-5 and 9-10, where reversed events are missing and within normal chron 15 where one normal event is missing. The absence of these short chrons is attributed either to insufficient sampling or to minor absences in the rock/time record. Despite the good average sampling density of $0.22,0.25$ and 0.30 samples $/ \mathrm{m}$ for chrons $\mathrm{d}, \mathrm{h}$ and 15 , respectively, sampling intervals can reach $\sim 0.07$ samples $/ \mathrm{m}$ in the reversed $\mathrm{d}$ chron, and 0.12 samples/m in the reversed $h$ chron. Our preferred correlation constrains the sedimentary section to span from 3.1 to $10.5 \mathrm{Ma}$, which corresponds to a relatively constant sedimentation rate with an average of $0.21 \pm 0.01 \mathrm{~mm} / \mathrm{year}$ (Fig. $6 \mathrm{f}$ ). However, the much lower sampling density in the conglomerate-rich part near the top of the section leads to a larger uncertainty associated with chrons 4 to 1. 


\section{Rock magnetism}

Time-transgressive changes in rock magnetic parameters can be very useful in tracking potential changes in sediment source, sediment transport conditions, etc., which can occur during basin formation. For example, the susceptibility of magnetite is w1000 times greater than other common minerals [29], and thus the bulk susceptibility $(k)$ of rocks is sensitive to magnetite concentration. Because magnetite is generally more abundant in crystalline basement rocks than in sediments, tracking time-variations in $k$ can yield important information as to when basement rocks became exposed and eroded [30]. Fig. 7a shows $k$ as a function of depth for the Kuitun section, where $k$ ranges from $\approx 50$ to $\approx 1000 \times 10^{-6}$ S.I. Although long wavelength variations clearly exist, $k$ does not undergo significant change that would signal a radical departure in source.

To confirm the $k$ data, which could potentially be biased by other mineral phases in the rock, we measured the anhysteretic remanent magnetization (ARM) of the samples using a continuous applied field of $10^{4} \mathrm{nT}$ and a peak AF field of $85 \mathrm{mT}$. Under these conditions, the ARM intensity $\left(J_{\text {ARM }}\right)$ should be sensitive solely to magnetite. We plotted $J_{\text {ARM }}$ as a function of depth (Fig. 7b), where a very good correlation with $\mathrm{k}$ is observed. Taken together, we find that magnetite concentration undergoes broad variations with a maximum at about $\sim 8 \mathrm{Ma}$ and minimums at $\sim 7$ and $\approx 5.5 \mathrm{Ma}$, yet there is nothing in the signal to suggest a radical departure in source characteristics.

Another piece of valuable information comes from anisotropy of magnetic susceptibility (AMS). From AMS measurements, one can calculate the degree of anisotropy $\left(P_{\mathrm{j}}\right)$ [31] as well as the shape parameter $(T)$ [32]. $P_{\mathrm{j}}$ can be sensitive to lithology changes or as a proxy for strain, while $T$ can yield information related to the hydrologic regime and transport conditions experienced by the sediments. For example, high anisotropy can signal greater amounts of compaction or sediment compositions that are more prone to compaction. $T$ values close to 0 indicate that the average particle shape in the sample is spherical, positive values correspond to oblate-shaped particles and negative values to prolate-shaped particles. 


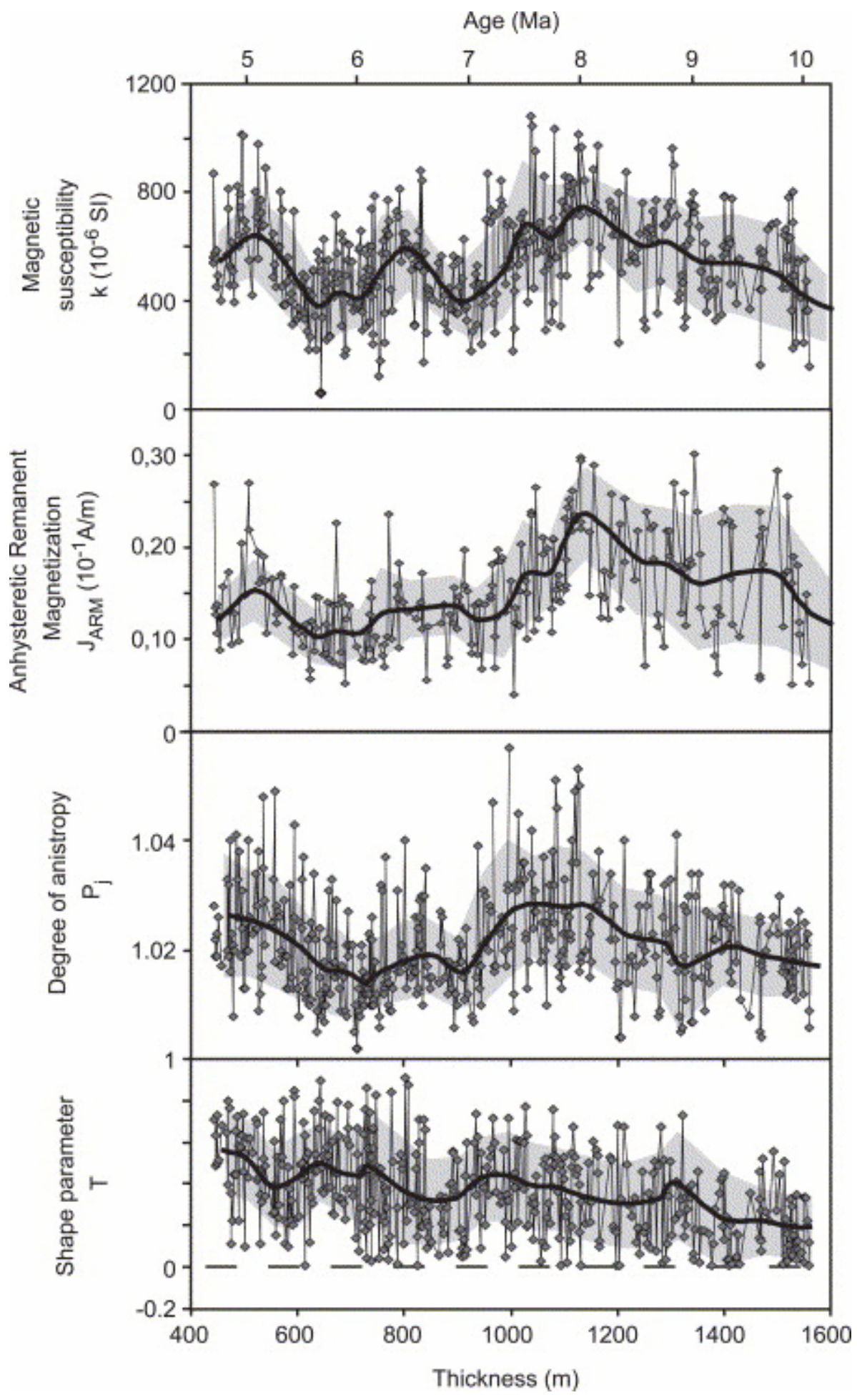

Fig. 7. Variations of magnetic susceptibility $(k)$, anhysteretic remanent magnetization $\left(J_{\text {ARM }}\right)$, anisotropy degree $\left(P_{\mathrm{j}}\right)$ and shape parameter $(T)$ as a function of depth and time for the Kuitun He section. Heavy solid line shows the averages of a sliding window shifted every $50 \mathrm{~m}$; 10 uncertainties in grey. 
The depth-dependent variations in $P_{\mathrm{j}}$ and $T$ for the Kuitun section are shown in Fig. 7c and $d$. $P_{\mathrm{j}}$ ranges from 1.00 to 1.06 , with an average of $1.02 \pm 0.01$ (e.g. $2 \pm 1 \%$ anisotropy), signalling that the Kuitun sediments have experienced only very weak deformation and/or compaction. It is interesting to note that variations in $P_{\mathrm{j}}$ roughly mimic the variations in magnetite content $\left(K\right.$ and $J_{A R M}$ ). The shape parameter $T$ ranges from 0 to 0.91 with a mean of $0.4 \pm 0.2$. $T$ is clearly oblate on average, yet here a long-term trend is apparent with smaller values at the base of the section going to larger values towards the top. This trend does not correlate with either $k$ or $J_{\text {ARM }}$ meaning that the shape parameter $T$ is not dependent on magnetite concentration.

\section{Disc ussion}

Sun et al. [33] recently published a magnetostratigraphic study from a section $5 \mathrm{~km}$ east of the Kuitun section, which we refer to as the Dushanzi section. Although the Dushanzi section spans less time than the Kuitun section, the two sections have roughly similar magnetostratigraphies, with both possessing three relatively long reversed chrons separated by periods of high reversal frequency (Fig. 6c and d). However, there are some notable discrepancies. Assuming our proposed correlation between the two Dushanzi and Kuitun column is correct, the main incompatibilities are found in Kuitun chrons 4, 6 and h, where Sun et al. [33] identified more polarity intervals (see Fig. 5 of [33]). Based on our longer polarity column, we propose an alternative correlation of the Dushanzi magnetostratigraphic polarity column that shifts the top of that section to be older by $\approx 1.2 \mathrm{Ma}$ than proposed by Sun et al. [33]. This new correlation matches better with the reference scale in terms of reversal frequency.

As the Xiyu Formation conglomerates are widely recognized throughout Central Asia as marking an important tectonic and/or climatic event, several studies have been carried out to constrain their age. At the Kuitun section, it appears that the more fine-grained sediments of the Neogene Dushanzi Formation grade progressively into the coarse conglomerates typically assigned to the Xiyu Formation, without the presence of a marked angular unconformity. The absence of an angular unconformity could indicate that the sediments exposed along the Kuitun River were deposited far enough from the range front that they were not subjected to synsedimentary deformation related to the growing Tianshan. Despite these caveats, we assume that the base of the conglomerate-rich part in the Kuitun section $1<444$ $\mathrm{m}$ ) corresponds to the base of the Xiyu Formation based on their classic definition [33].

According to the correlation established in this study, the age of the base of the Xiyu Formation is about $4.8 \mathrm{Ma}$, which is older than the commonly sited early Pleistocene age [15], [34] and [35]. The magnetostratigraphic study of Sun et al. [33], dated the base of the formation as $2.98 \mathrm{Ma}$, which we re-interpret as $\sim 4.2 \mathrm{Ma}$. Studies from Tianshan's southern flank [36] and the western piedmont of the western Kunlun [37] have dated the base as 2.8 and 3.5-4.5 Ma, respectively. These age differences may indicate that the deposition of the Xiyu conglomerates is diachronous across the Tianshan. This observation also implies that stratigraphic ages defined solely by facies correlation contain inherently large uncertainties ( $\geq 2 \mathrm{My}$ ), especially in orogenic foreland basins. 
As mountains grow higher, erosion rates tend to increase (e.g. [38]), which leads to heightened sediment input into the catchment basins surrounding the mountains [39] and [40]. However, absolute dating of the sediments and establishing wellquantified deposition rates have proven extremely difficult in the continental sediments of central Asia, which are notorious for lacking diagnostic fossils or volcanic layers to date with geochronology. This is why magnetostratigraphy remains the best available tool to date fossil-poor sediments. Despite this, problems with the accuracy of the method, as shown above, suggests that one must interpret the result, and their implications with caution.

Several detailed magnetostratigraphic studies have been carried out in Asia, for example, at the front of Himalayan mountains in the Siwalik (e.g. [41]), in the Potwar Plateau [42], in the Rudgai basin [43]; surrounding the Tibetan Plateau in the Subei area in the front of the Qaidam basin [30], in the Guide basin within the Qilian Shan (e.g. [44]), within the Kunlun Shan [37], as well as around the Tianshan [33] and [36]. For sediments younger than $\approx 20 \mathrm{Ma}$, these magnetostratigraphic studies have found that the average sedimentation rates are fairly uniform at the localities surrounding the Tibetan plateau: being $25 \mathrm{~cm} / \mathrm{ky}$ for Rudgai basin [43], $33 \mathrm{~cm} / \mathrm{ky}$ for Subei [30], 22 $\mathrm{cm} / \mathrm{ky}$ for the Guide basin [44], while the sedimentation rate at the front of the Himalaya varies between 13 and $50 \mathrm{~cm} / \mathrm{ky}$ [41]. The sedimentation rate of $21 \mathrm{~cm} / \mathrm{ky}$ for the Kuitun section lies well within the realm of the other studies. However, this value differs from the southwestern Chinese Tianshan [36] that exhibits an average sedimentation rate of around $8 \mathrm{~cm} / \mathrm{ky}$ during the last $\approx 3.5 \mathrm{Ma}$.

An interesting result that is now coming to light in some of these studies is that sedimentation rate remains relatively constant throughout the sampled sections. It remains unclear whether the absence of acceleration in the sedimentation rate is because the time sampled in the various sections was younger than the onset of uplift. An important point is that this is true regardless of observed changes in lithology. For example, in Subei, the sediments clearly coarsen with time yet no longterm change in deposition rate was observed [30]. The same is true for the Boguzihe and Ganhangou sections in west Tarim [36]. Except for the conglomerate-rich part at the top of the section where the correlation is less certain, the same is true for the Kuitun section, which has a relatively constant sedimentation rate of $21 \pm 1 \mathrm{~cm} / \mathrm{ky}$ from the period spanning 10.5 to $4.8 \mathrm{Ma}$. We interpret the absence of acceleration of the sedimentation rate as evidence that the major uplift of the Tianshan should be older than $\approx 10.5 \mathrm{Ma}$. The upward coarsening of the sediments would then essentially reflect progradation of the sediments over the underthrusting Junggarian basement.

Foreland basins like the Junggar basin develop characteristic sedimentation patterns that are a function of the distance from the front of the orogenic wedge to the place of regional subsidence [45] and [46]. Deposition zones more proximal to the source will contain coarser sediments as opposed to more distal deposition zones that will possess finer-grained sediments, which travelled farther in distance and time. During progressive shortening, the sediments are progressively incorporated into the foothill fold-and-thrust belt as the front wedge propagates. Thus at a fixed point of the basin, the sediments coarsen upwards through time because they are deposited closer and closer to the approaching orogenic front. This is why depth variations of rock magnetic parameters, such as those of AMS, can serve to track changes in transport regime (stream velocity, distance travelled from source, etc.), which can accompany tectonic and/or climate changes. For example, at the Subei section a 
few kilometres from the Altyn Tagh fault on the Qaidam basin, Gilder et al. [30] found that the $T$ parameter changed abruptly at $21 \mathrm{Ma}$ from being spherical on average $(T=0)$ to being distinctly oblate $(T>0)$. They interpreted this change to reflect a difference in transport conditions of the particles. When $T$ is near 0 , they argued that the particles were transported far enough that they became sufficiently eroded to be spherical on average. As the encroaching mountain approaches the basin, the grains travel less distance to their final deposition sites, meaning that the grains are eroded less and are oblate on average, for the same reason clasts in conglomerates are oblate on average.

Thus, for the Kuitun section, we interpret the constant change in the $T$ parameter toward more positive values from the bottom to the top as reflecting the encroachment of the Tianshan mountains toward the deposition site. Assuming our magnetostratigraphic correlation is correct, this is again consistent with the interpretation that uplift was active in the region before $10.5 \mathrm{Ma}$ and reinforces the majority of existing work suggesting the initiation of the Tianshan uplift to be older than $10 \mathrm{Ma}$ [13], [19] and [20]. Accepting that exhumation of the western Kyrgyz Tianshan started by $\approx 11 \mathrm{Ma}$ [19] and [20], combined with our present findings, suggests that the uplift of the Tianshan was likely synchronous from west to east. Finally, the stable sedimentation rates and the progressive change in the $T$ parameter toward more positive values implies a relative constant tectonic regime and justifies extrapolating the present-day shortening rates to the past [11] and [13].

\section{Acknowledgements}

This study was financed by the French program ECLIPSE and the Chinese project 973 No. G1999043303 and No. 1999043509. We thank Peter Molnar and Lisa Tauxe for their very constructive reviews. This is IPGP contribution 2924.

\section{References}

[1] P.A. Patriat and J. Achache, India-Eurasia collision chronology has implications for crustal shortening and driving mechanisms of plates, Nature 311 (1984), pp. 615-621.

[2] M.E. Raymo and W.F. Ruddiman, Tectonic forcing of late cenozoic climate, Nature 359 (1992), pp. 117-122.

[3] F. Fluteau, G. Ramstein and J. Besse, Simulating the evolution of the Asian and African monsoons during the past 30 millions years using an atmopsheric general circulation model, J. Geophys. Res. 104 (1999), pp. 11995-12018.

[4] W.F. Ruddiman and J.E. Kutzbach, Forcing of late Cenozoic northern hemisphere climate by plateau uplift in southern Asia and the American West, J. Geophys. Res. 94 (1989), pp. 18409-18427.

[5] F. Métivier and Y. Gaudemer, Mass transfer between eastern Tien Shan and adjacent basins (central Asia): constraints on regional tectonics, Geophys. J. Int. 128 (1997), pp. 1-17. 
[6] P. Tapponnier, Z. XU, F. Roger, B. Meyer, N. Arnaud, G. Wiltinger and J. Yang, Oblique stepwise rise and growth of the Tibet Plateau, Science 294 (2001), pp. 16701677.

[7] J.-P. Avouac and P. Tapponnier, Kinematic model of active deformation in central Asia, C. R. Acad. Sci., Paris 315 (1992) (II), pp. 1791-1798.

[8] Y. Chen, S. Gilder, J.P. Cogné and V. Courtillot, New Mesozoic and Cenozoic paleomagnetic data help contsrain the age of motion on the Altyn Tagh fault and rotation of the Qaidam basin, Tectonics 21 (2002) (5), pp. 1-19.

[9] V.S. Burtman, Structural geology of the Variscan Tian Shan, USSR, Am. J. Sci. 275-A (1975), pp. 157-186.

[10] B.F. Windley, M.B. Allen, C. Zhang, Z.-Y. Zhao and G.R. Wang, Paleozoic accretion and Cenozoic deformation of the Chinese Tien Shan Range, central Asia, Geology 18 (1990), pp. 128-131.

[11] K.Y. Abdrakhmatov, S.A. Aldazhanov, B.H. Hager, M.W. Hamburger, T.A. Herring, K.B. Kalabaev, V.I. Makarov, P. Molnar, S.V. Panasyuk, M.T. Prilepin, R.E. Reilinger, I.S. Sadybakasov, B.J. Souter, Y.A. Trapeznikov, V.Y. Tsurkov and A.V. Zubovich, Relatively recent construction of the Tien Shan inferred from GPS measurements crustal deformation rates, Nature 384 (1996), pp. 450-453.

[12] C. Reigber, G.W. Michel, R. Galas, D. Angermann, J. Klotz, J.Y. Chen, A. Papschev, R. Arslanov, V.E. Tzurkov and M.C. Ishanov, New space geodetic constraints on the distribution of deformation in the Central Asia, Earth Planet. Sci. Lett. 191 (2001), pp. 157-165

[13] J.-P. Avouac, P. Tapponnier, P. Bai, M. You and G. Wang, Active Thrusting and folding along the northern Tien Shan and late Cenozoic rotation of the Tarim relative to Dzungaria and Kazakhstan, J. Geophys. Res. 98 (1993), pp. 11791-11808.

[14] M.S. Hendrix, A.S. Graham, A.R. Carroll, E.R. Sobel, C.L. McKnight, B.J. Schulein and Z. Wang, Sedimentary record and climatic implications of deformation in the Tian Shan: evidence from Mesozoic strata of the north Tarim, south Junggar, and Turpan Basins, northwest China, Geol. Soc. Amer. Bull. 104 (1992), pp. 53-79.

[15] B.C. Burchfiel, E.T. Brown, Q. Deng, X. Fang, P. Molnar, J. Shi, W. ZZhangming and Y. Huichan, Crustal Shortening on the Margins of the Tian Shan, Xinjiang, China, Int. Geol. Rev. 41 (1999), pp. 663-700.

[16] Y. Yang and M. Liu, Cenozoic deformation of the Tarim plate and the implications for mountain building in the Tibetan Plateau and the Tian Shan, Tectonics 21 (2002) (6), pp. 9-1-9-16.

[17] B. Fu, A. Lin, K.-I. Kano, T. Maruyama, J. Guo and K.Y. Abdrakhmatov, Quaternary folding of the eastern Tian Shan, northwest China, Tectonophysics 369 (2003), pp. 79101. 
[18] T. Liu, M. Ding and E. Derbyshire, Gravel Deposits on the margins of the QinghaiXizang plateau, and their environemental significance, Palaeogeogr. Palaeoclimatol. Palaeoecol. 120 (1996), pp. 159-170.

[19] M.E. Bullen, D.W. Burbank and J.I. Garver, Building the northern Tien Shan: integrated thermal, structural, and topographic constraints, J. Geol. 111 (2003), pp. 149-165.

[20] M.E. Bullen, D.W. Burbank, J.I. Garver and K.Y. Abdrakhmatov, Late Cenozoic tectonic evolution of the northwestern Tien Shan: new age estimates for the initiation of mountain building, Bull. Geol. Soc. Am. 113 (2001) (12), pp. 1544-1559.

[21] Bureau of Geological and Mineral Resources of the Xinjiang Uygur, Autonomous Region, Regional geology of Xinjiang Uygur Autonomous region, People's Republic of China ministry of geology and mineral resources, Geol. Mem. 1 (1993) (32) (841 pp.).

[22] J.L. Kirschwink, The least-square line and plane and the analysis of paleomagnetic data, Geophys. J. R. Astron. Soc. 62 (1980), pp. 699-712.

[23] R.A. Fisher, Dispersion on a sphere, Proc. R. Soc. 217 (1953) (Ser. A), pp. 295-302.

[24] J.P. Cogné, Paleomac: a Macintosh TM application for treating paleomagnetic data and making plate reconstructions, Geochem. Geophys. Geosyst. 4 (2003) (1), p. 1007.

[25] L. Tauxe, Paleomagnetic Principles and Practice, Kluwer Academic Publisher (1998) 312 pp..

[26] P.L. McFadden and M.W. McEhlinny, Classification of the reversal test in paleomagnetism, Geophys. J. Int. 103 (1990), pp. 725-729.

[27] M.W. McEhlinny and P.L. McFadden, Statistical significance of the fold test in paleomagnetism, Geophys. J. R. Astron. Soc. 7 (1964), pp. 457-468.

[28] W.A. Berggren, D.V. Kent, C.C. Swisher and M.-P. Aubry, A revised geochronology and chronostratigraphy, Geochronology Time Sclaes and Global Stratigraphic Correlation, Special Publication SEPM vol. 54 (1995).

[29] D.W. Collinson, Methods in Rock Magnetism and Paleomagnetism: Techniques and Instrumentation, Chapman and Hall, New York (1983) 503 pp..

[30] S. Gilder, Y. Chen and S. Sevket, Oligo-Miocene magnetostratigraphy and rock magnetism of the Xishuigou section, Subei (Gansu Province, western China) and implications for shallow inclinations in central Asia, J. Geophys. Res. 106 (2001) (12), pp. 30505-30521.

[31] V. Jelinek, Characterization of the magnetic fabrics of rocks, Tectonophysics 79 (1981), pp. 63-67.

[32] F. Hrouda, Magnetic anisotropy of rocks and its application to geology and geophysics, Geophys. Surv. 5 (1982), pp. 37-82. 
[33] J. Sun, R. Zhu and J. Bowler, Timing of the Tianshan Mountains uplift constrained by magnetostratigraphic analysis of molasse deposits, Earth Planet. Sci. Lett. 219 (2004), pp. 239-253.

[34] H. Chen, X.L. Lin, K.N. Guan and J.M. XU, Early Pleistocene deposits and its lower boundary (Q/N) in Tian Shan MT, Xinjiang region, Quat. Sci. 1 (1994), pp. 38-47.

[35] Z.H. Teng, L.P. Yue, R.H. Pu, X.Q. Deng and X.W. Bian, The magnetostratigraphic age of the Xiyu Formation, Geol. Rev. 42 (1996), pp. 481-489.

[36] J. Chen, D.W. Burbank, K.M. Scharer, E. Sobel, Y. Jinhui, C. Rubin and Z. Ruibin, Magnetochronology of the Upper Cenozoic strata in the Southerstern Chinese Tian Shan: rates of Pleistocene folding and thrusting, Earth Planet. Sci. Lett. 6075 (2001), pp. 1-19.

[37] H.B. Zheng, C.M. Powell, Z. An, J. Zhou and G. Dong, Pliocene uplift of the northern Tibetan Plateau, Geology 28 (2000) (8), pp. 715-718.

[38] D.W. Burbank, J. Leland, E. Fielding, R.S. Anderson, N. Brozovic, M.R. Ried and C. Duncan, Bedrock incision, rock uplift and threshold hillslopes in the northwestern Himalayas, Nature 379 (1996), pp. 505-510.

[39] F. Métivier, Y. Gaudemer, P. Tapponnier and K. Michel, Mass accumulation rates in Asia during the Cenozoic, Geophys. J. Int. 137 (1999), pp. 280-318.

[40] D.W. Burbank, L.A. Derry and C. France-Lanord, Reduced Himalayan sediment production 8 Myr ago despite an intensified monsoon, Nature 364 (1993), pp. 48-50.

[41] E. Appel, W. Rösler and G. Corvinus, Magnetostratigraphy of the MiocenePleistocene Surai Khola Siwaliks in West Nepal, Geophys. J. Int. 105 (1991), pp. 191198.

[42] N.D. Opdykes, E. Lindsay, N. Johnson, R.A.K. Tahirkheli and M.A. Mirza, Magnetic polarity stratigraphy and vertebrate paleantology of the upper Siwaliksub-Group of northern Pakistan, Palaeogeogr. Palaeoclimatol. Palaeoecol. 27 (1979), pp. 1-34.

[43] K.H. Durani, Y. Chen, M.-D. Courme and A. Kassi, Etude magnétostratigraphique préliminaire sur l'âge du bassin de Rudgai-Sibi (Nord-Est du Balouchistan, Pakistan) et ses implications tectonqives, C. R. Acad. Sci., Paris 325 (1997), pp. 11-18.

[44] J.M. Parès, R. Van der Voo, W.R. Downs, M. Yan and X. Fang, Northeasward growth of the Tibetan Plateau: magnetostratigraphic insights from the Guide basin, J. Geophys. Res. 108 (2003), pp. 1-11.

[45] P.G. DeCelles, G.E. Gehrels, J. Quade and P. Ojha, Eocene-early Miocene foreland basin development and the history of Himalayan thrusting, western and central Nepal, Tectonics 17 (1998) (15), pp. 741-765.

[46] P.G. DeCelles and K.A. Giles, Foreland basin systems, Basin Res. 8 (1996), pp. 105123. 
[47] J.D.A. Zijderveld, A.C. demagnetization of rocks: analysis of results In: D.W. Collinson, K.M. Creer and S.K. Runcorn, Editors, Methods in Paleomagnetism (1967), pp. 254-286. 